Clim. Past Discuss., https://doi.org/10.5194/cp-2017-96

Manuscript under review for journal Clim. Past

Discussion started: 23 August 2017

(c) Author(s) 2017. CC BY 4.0 License.

\title{
A revised Law Dome age model (LD2017) and implications for last glacial climate
}

Jason Roberts ${ }^{1,2}$, Andrew Moy ${ }^{1,2}$, Christopher Plummer ${ }^{2,3}$, Tas van Ommen ${ }^{1,2}$, Mark Curran ${ }^{1,2}$, Tessa Vance ${ }^{2}$, Samuel Poynter ${ }^{2}$, Yaping Liu ${ }^{4}$, Joel Pedro ${ }^{5}$, Adam Treverrow ${ }^{2}$, Carly Tozer ${ }^{2,6}$, Lenneke Jong $^{2,3}$, Pippa Whitehouse ${ }^{7}$, Laetitia Loulergue ${ }^{8}$, Jerome Chappellaz $^{8}$, Vin Morgan ${ }^{1,2}$, Renato Spahni ${ }^{9}$, Adrian Schilt ${ }^{9}$, Cecilia MacFarling Meure ${ }^{10}$, David Etheridge ${ }^{10}$, and Thomas Stocker ${ }^{9}$

${ }^{1}$ Australian Antarctic Division, Kingston, Tasmania 7050, Australia

${ }^{2}$ Antarctic Climate \& Ecosystems Cooperative Research Centre, University of Tasmania, Hobart, Tasmania 7001, Australia

${ }^{3}$ Institute for Marine and Antarctic Studies, University of Tasmania, Hobart, Tasmania 7001, Australia

${ }^{4}$ State Key Laboratory of Cryospheric Sciences, Northwest Institute of Eco-Environment and Resources, CAS, Lanzhou, 730000, China

${ }^{5}$ Center for Ice and Climate, Niels Bohr Institute, University of Copenhagen, Copenhagen 2100, Denmark

${ }^{6}$ Faculty of Science \& Information Technology, University of Newcastle, Callaghan, New South Wales 2308, Australia

${ }^{7}$ Department of Geography, Durham University, Durham, DH1 3LE, UK

${ }^{8}$ University Grenoble Alpes, CNRS, IRD, Grenoble INP, IGE, F-38000 Grenoble, France

${ }^{9}$ Climate and Environmental Physics, Physics Institute and Oeschger Centre for Climate Change Research, University of Bern, Sidlerstrasse 5, CH-3012 Bern, Switzerland

${ }^{10}$ Climate Science Centre, CSIRO Oceans and Atmosphere, Aspendale Victoria 3195 Australia

Correspondence to: Jason Roberts (Jason.Roberts@aad.gov.au)

Abstract. Here we present a revised Law Dome, Dome Summit South (DSS) ice core age model (denoted LD2017) that significantly improves the chronology over the last $88 \mathrm{ka}$. An ensemble approach was used, allowing for the computation of both a median age and associated uncertainty as a function of depth. The revised chronology incorporates extended continuous annual layer counting to $853 \mathrm{~m}$ using chemical species with seasonally-varying behaviours. The annual layer counted age at $853 \mathrm{~m}$ is 2332 years before 2000 ( $\mathrm{y} \mathrm{b} 2 \mathrm{k}$ ) with an error of $+13 /-7$ y, i.e. $2345-2325 \mathrm{y} \mathrm{b} 2 \mathrm{k}$. Below this depth, non-linear interpolation between age ties using a probability density function for age/depth is used to constrain and model the age of the ice. The ice-based age ties below the annual layer counted section are based on matching volcanic event markers, methane $\left(\mathrm{CH}_{4}\right)$ gas concentration, isotopic composition of ice $\left(\delta^{18} \mathrm{O}\right)$ and the Last Glacial Maximum (LGM) dust peak to other records. For consistency, the timescale used for all matching is the AICC2012 timescale (Veres et al., 2013). The first ice-based age tie is the base of the annual layer counting record ( $2332 \mathrm{y} \mathrm{b2k}$ ) and the age ties from $\sim 2400-4000 \mathrm{y} \mathrm{b} 2 \mathrm{k}$ are volcanic synchronised ice-based age ties. The detection of abrupt changes in $\mathrm{CH}_{4}$ gas concentrations within the DSS record provides further independent gas-based age ties, including the tightly constrained $8200 \mathrm{y} \mathrm{b} 2 \mathrm{k}$ event. The improved age control between 9000 and $21000 \mathrm{y} \mathrm{b} 2 \mathrm{k}$ is supplemented by $\mathrm{CH}_{4}$ and $\delta^{18} \mathrm{O}$ ice measurements (Pedro et al., 2011). Over the period 16600 to $18600 \mathrm{y} \mathrm{b} 2 \mathrm{k}$ large changes in dust concentration, matched to the EDC dust record, are used to constrain two ice-based age ties. Unlike previous studies, where the modelling was used to simultaneously infer both age and snow accumulation rate, we made an independent estimate of the snow accumulation rate, where required, for the use of gas based age ties. 
Clim. Past Discuss., https://doi.org/10.5194/cp-2017-96

Manuscript under review for journal Clim. Past

Discussion started: 23 August 2017

(c) Author(s) 2017. CC BY 4.0 License.

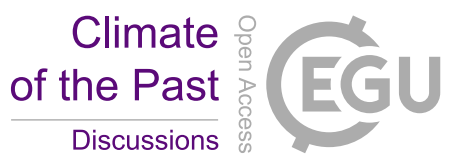

\section{Introduction}

Law Dome is a small ( $\sim 200 \mathrm{~km}$ diameter), independent ice cap situated on the coast of East Antarctica. The site has a maritime climate and is strongly influenced by easterly airflow produced by low-pressure systems centred around $65^{\circ} \mathrm{S}$ (Curran et al., 1998; Morgan et al., 1997). The primary ice core drilling site is Dome Summit South (DSS) located approximately

$54.7 \mathrm{~km} \mathrm{SSW}$ of the Law Dome Summit $\left(66.7697^{\circ} \mathrm{S}, 112.8069^{\circ} \mathrm{E}\right)$ at an elevation of $1370 \mathrm{~m}$. The site has a high, relatively temporally uniform accumulation $\left(\sim 0.7 \mathrm{~m} \mathrm{y}^{-1}\right.$ ie, ice equivalent metres per year, based on an ice density of $\left.917 \mathrm{~kg} \mathrm{~m}^{-3}\right)$, low surface temperatures (mean annual temperature of $-21.8^{\circ} \mathrm{C}$ ) which preclude summer melt and relatively moderate wind speed $\left(8.3 \mathrm{~m} \mathrm{~s}^{-1}\right)$ which results in clear annual layer definition (Morgan et al., 1997; Roberts et al., 2015).

The Law Dome DSS ice core record is primarily based on a single deep core, which is described in Morgan and van Ommen (1997). The main DSS core (DSS-main) is augmented in the upper portion by splicing three overlapping ice cores, namely DSS99, DSS97, and DSS1213 to DSS-main that cover the epochs 1841-1887, 1888-1988 and 1989-2012 CE (Roberts et al., 2015). The purpose of the additional cores is twofold: first to improve sampling and measurement integrity, and second to extend the record forward in time to 2012 CE (Plummer et al., 2012). The upper $\sim 125 \mathrm{~m}$ of the original DSS-main ice core is affected adversely in places by melt-percolation in the thermally drilled firn portion, and by poor core quality through a region where the main electromechanical drill was commissioned. Additionally, improved analytical controls provided higher quality water stable isotope and trace ion chemistry measurements on the DSS97 and other recent DSS ice cores than previous early shallow sections of DSS.

The previous Law Dome DSS age model (LD1) was derived from a combination of annual layer counting, stratigraphic markers and flow modelling techniques (van Ommen and Morgan, 1996, 1997; van Ommen et al., 2004). Measured annual layers provided flow-thinning data which constrain a model-fit of the ice flow. The layer-thickness constraints required knowledge of the long-term palaeo-accumulation, which, for the latter half of the Holocene up to the preindustrial, is likely to have been unaffected by major systematic variation (van Ommen et al., 2004). Additional constraints on this model, which do not depend so strongly on palaeo-accumulation, arise from various independently dated horizons in the lower ice-sheet. These include the use of air-composition measurements at DSS $\left(\delta^{18} \mathrm{O}\right.$ of $\mathrm{O}_{2}$ and methane concentrations) to tie deglacial changes (Morgan et al., 2002; Pedro et al., 2011) to GRIP and GICC05 chronology. The precision of the record through this period ( 9-19 ky b2k) is discussed by Morgan et al. (2002) and is limited by uncertainties in the firn air-trapping and hence offset between ice and gas ages, which arise from uncertainties in temperature and accumulation.

Here we present the revised Law Dome DSS ice core age model that improves the chronology presented by Morgan et al. (2002) and van Ommen et al. (2004) using new data. The revised chronology incorporates the extended annual layer counting to 2332 years (Plummer et al., 2012; Roberts et al., 2015), and the improved age control between 9 and 21 ky that is supplemented by methane $\left(\mathrm{CH}_{4}\right)$ and $\delta^{18} \mathrm{O}$ ice measurements (Pedro et al., 2011). Compared to LD1, the new age scale has an additional $1545 \mathrm{y}$ of annual layer counting, nine additional age ties, age and depth uncertainties for each individual age tie (compared to the bulk age uncertainty of $200 \mathrm{y}$ during the Holocene for LD1) that are propagated throughout the age model, revised depths for some age ties, and revised ages at the tie points. Overall, the difference in the ages at the LD1 age ties range between 11 
Clim. Past Discuss., https://doi.org/10.5194/cp-2017-96

Manuscript under review for journal Clim. Past

Discussion started: 23 August 2017

(c) Author(s) 2017. CC BY 4.0 License.

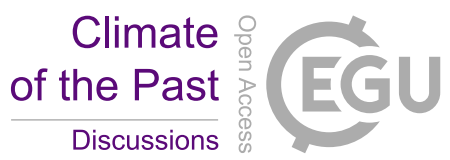

and $2042 \mathrm{y}$. The maximum depth of the oldest age tie is clightly reduced in the current age model (1182.302 m compared to $1182.657 \mathrm{~m}$ ) while the corresponding age is slightly increased (88012 y b2k compared to $87212 \mathrm{yb} 2 \mathrm{k}$ ). The revised Law Dome DSS age model is denoted LD2017.

The age-scale uses continuous annual layer counting and ice and gas age ties to other records. The age ties below the annual

5 layer counted section are based on matching Law Dome volcanic event markers, methane gas concentration $\left(\mathrm{CH}_{4}\right)$, isotopic composition of ice $\left({ }^{18} \mathrm{O}\right)$ and the Last Glacial Maximum (LGM) dust peak to other records. For consistency, the timescale used for all matching is the AICC2012 timescale (Veres et al., 2013), although gas-based age ties via direct $\left(\mathrm{CH}_{4}\right)$ gas-matching (Morgan et al., 2002; Pedro et al., 2011) use the GICC05 timescale. The AICC2012 timescale is an optimised multi-parameter and multi-site chronology developed from four Antarctic ice core records and is virtually identical to the layered counted GICC05 timescale for the last $60.2 \mathrm{ky}$ (Veres et al., 2013).

Unlike some previous studies, this model does not simultaneously infer ages and accumulation, as in essence this propagates all errors in the ice physics into estimates of the accumulation. Rather, we estimate the accumulation independently, where required for the use of gas based age ties.

Age models that rely on linear interpolation between age ties suffer from several shortcomings. The layer thicknesses in the upper part of the interval between age ties tend to be too thin (and hence ages change too quickly) and conversely the layer thicknesses are too thick in the lower part (and ages change too slowly). In addition, there is a discontinuity in layer thickness (and hence implied accumulation rates) at the age ties. The age model used here aims to minimise these discontinuities in the layer thicknesses at the age ties by using a piece-wise parabolic annual layer model. This is somewhat similar to the smoothest annual-layer model of Fudge et al. (2014), although we use updated age ties and also fully propagate uncertainties throughout our model and report both the median and standard deviation of age at depth. The age model at $1 \mathrm{~m}$ vertical resolution is given as Supplementary Information.

\section{Hybrid Age Model}

The Law Dome DSS ice core age model is derived from a combination of directly counted annual layers and age ties to other records. All depths are in actual metres (not ice equivalent metres) downward from the surface, and accumulation rates are in $\mathrm{my}^{-1}$ ie.

Annual layer counting is continuous down to $852.668 \mathrm{~m}$ using chemical species with seasonally-varying behaviours. These include water stable isotopes $\left(\delta^{18} \mathrm{O}\right.$ and $\left.\delta \mathrm{D}\right)$, hydrogen peroxide $\left(\mathrm{H}_{2} \mathrm{O}_{2}\right)$ and trace ion chemical species (non-sea-salt sulphate $\left(\mathrm{nssSO}_{4}^{2-}\right.$ ) and sea salt species $\left(\mathrm{Cl}^{-}, \mathrm{Na}^{+}\right.$and $\mathrm{Mg}^{2+}$ ) (Plummer et al., 2012). The annual layer counted age at $852.668 \mathrm{~m}$ is $2332 \mathrm{y} \mathrm{b} 2 \mathrm{k}$ with an error of $+13 /-7$ y, i.e. $2345-2325 \mathrm{y} \mathrm{b} 2 \mathrm{k}$. The age error reflects uncertainty in counting/data interpretation errors. Below this depth, non-linear interpolation between age ties reflects errors in the interpolation between age ties with uncertainty in both depth and age. This is a more stochastic process and assumes a probability density function (pdf) for age/positions. For the section below the annual layer counting, all ages are relative to the AICC2012 time-scale so all uncertainties are relative to AICC2012 and are not absolute. 
Clim. Past Discuss., https://doi.org/10.5194/cp-2017-96

Manuscript under review for journal Clim. Past

Discussion started: 23 August 2017

(c) Author(s) 2017. CC BY 4.0 License.

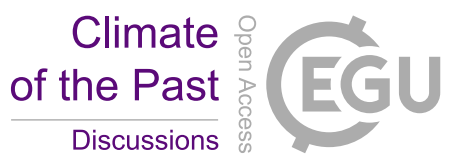

(c) (i)

\section{Age Ties}

Tables 1 and 2 list the ice and gas-based age ties used to constrain the revised Law Dome DSS age scale. Details relating to these age ties are given below.

\subsection{Ice-based age ties}

5 The first ice-based age tie is the base of the annual layer counting record that extends the annual layer counted record of Plummer et al. (2012) by $56.309 \mathrm{~m}$ (or $310 \mathrm{y}$ ). The continuous counting of annual layers down to $852.668 \mathrm{~m}$ is equivalent to $2332 \mathrm{yb} 2 \mathrm{k}$. The age ties from 2.4 to $4 \mathrm{ky} \mathrm{b2k}$ are volcanic synchronised ice-based age ties. The DSS volcanic record $\left(\mathrm{nssSO}_{4}^{2-}\right.$ ) are synchronised to the EPICA Dome C (EDC) dielectric profile (DEP) record (Parrenin et al., 2012) on the AICC2012 timescale. Volcanic events identified and synchronised are listed in Table 1. The reliable matching of volcanic events during the early Holocene was not possible due to the discontinuous DSS sulphate record resulting from poor core quality.

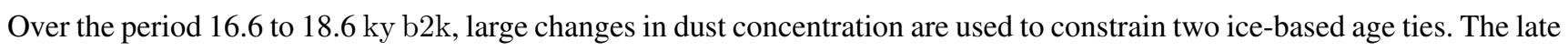
glacial dust concentration record for DSS is synchronised to the highly resolved EDC dust record (Lambert et al., 2008) on the AICC2012 timescale. Previous DSS dust concentration age ties were matched to the dust concentration records of the Antarctic

15 ice cores from Byrd and Vostok, which were tied to the GRIP age scale (van Ommen et al., 2004). The final ice-based age ties involve the synchronisation of the DSS $\delta^{18} \mathrm{O}$ and EDC $\delta^{18} \mathrm{O}$ records (Stenni et al., 2010) on the AICC2012 timescale. Like van Ommen et al. (2004) tie points were selected across Antarctic Isotope Maximum (AIM) events that show good agreement between the isotopic records, and with a minimum number of ties selected.

\subsection{Gas age ties}

20 Abrupt changes in $\mathrm{CH}_{4}$ gas concentrations within the DSS record provides further independent gas-based age ties (Table 2 ). The first of these two events occurs at the $8.2 \mathrm{ky}$ event where the DSS $\mathrm{CH}_{4}$ signal is tied to the GISP2 $\mathrm{CH}_{4}$ record (Kobashi et al., 2007) on the GICC05 time scale. The DSS $\mathrm{CH}_{4}$ record has a mean age sampling resolution of 12 y between $\sim 7.5$ and $8.3 \mathrm{ky}$ and is matched to the GISP2 $\mathrm{CH}_{4}$ record so that the large change in $\mathrm{CH}_{4}$ and the duration of the $\mathrm{CH}_{4}$ trough, is synchronised to the GISP2 $\mathrm{CH}_{4}$ during the $8.2 \mathrm{ky}$ event. Further air-composition measurements $\left(\delta^{18} \mathrm{O}\right.$ of $\mathrm{O}_{2}$ and $\mathrm{CH}_{4}$ concentrations) are used to tie the DSS deglacial changes (Morgan et al., 2002; Pedro et al., 2011) to GISP2 $\mathrm{CH}_{4}$ on the GICC05 timescale.

To convert the gas based age ties to equivalent ice-based age ties, we estimate the age offset ( $\Delta$ age) between the gas and icebased ages. This is a function of the density of the firn, which in turn requires estimates of the accumulation rate, temperature and impurity loading. We estimate the temperature from the water isotope data and the accumulation rate from upper and lower bounds that are based on vapour saturation pressure and upper heat flux respectively. 
Clim. Past Discuss., https://doi.org/10.5194/cp-2017-96

Manuscript under review for journal Clim. Past

Discussion started: 23 August 2017

(c) Author(s) 2017. CC BY 4.0 License.

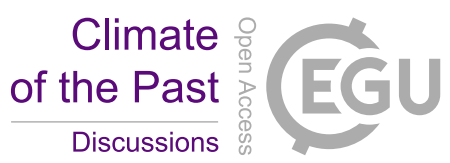

(c) (i)

Table 1. Ice-based age ties used in the LD2017 timescale

\begin{tabular}{lll}
\hline Depth $\mathrm{m}$ & Age y b2k & Age uncertainty y \\
\hline 761.020 & $1856^{a}$ & $+4 /-7$ \\
852.668 & $2332^{a}$ & $+15 /-8$ \\
868.16 & $2438.48^{b}$ & 20 \\
949.32 & $3374.83^{b}$ & 20 \\
951.98 & $3421.48^{b}$ & 20 \\
952.6 & $3431.33^{b}$ & 20 \\
966.49 & $3675.96^{b}$ & 20 \\
970.31 & $3735.52^{b}$ & 20 \\
987.43 & $4053.86^{b}$ & 20 \\
1130.895 & $16630^{c}$ & 328 \\
1132.220 & $18618^{d}$ & 328 \\
1156.082 & $48112^{e}$ & 1000 \\
1164.717 & $60312^{f}$ & 1000 \\
1170.452 & $72212^{g}$ & 2000 \\
1172.792 & $75812^{h}$ & 2000 \\
1179.542 & $84012^{i}$ & 2000 \\
1182.302 & $88012^{j}$ & 2000
\end{tabular}

\footnotetext{
${ }^{a}$ Annual layer counting

${ }^{b}$ Volcanic synchronisation to EDC(AICC2012)

${ }^{c}$ Dust, trailing edge of decrease after LGM with EDC(AICC2012)

${ }^{d}$ Dust, LD LGM maximum match with EDC(AICC2012)

${ }^{e} \delta^{18} \mathrm{O}$ pick of minima between AIM12/AIM13 with EDC (AICC2012)

${ }^{f} \delta^{18} \mathrm{O}$ pick of AIM17 match with EDC (AICC2012)

${ }^{g} \delta^{18} \mathrm{O}$ pick of AIM19 match with EDC (AICC2012)

${ }^{h} \delta^{18} \mathrm{O}$ pick of AIM20 match with EDC (AICC2012)

${ }^{i} \delta^{18} \mathrm{O}$ pick of AIM21 match with EDC (AICC2012)

${ }^{j} \delta^{18} \mathrm{O}$ pick of minima between AIM21/AIM22 in EDC @

ca 88 ky (on AICC2012 agescale)
}

Estimates of surface temperature from average $\delta^{18} \mathrm{O}$ values for \pm 30 y either side of gas-based age tie points are made, assuming a modern surface temperature of $-22{ }^{\circ} \mathrm{C}$, a modern $\delta^{18} \mathrm{O}$ isotope value of $22 \%$ and a slope in the range $0.44-$ $0.7 \%{ }^{\circ} \mathrm{C}^{-1}$. This gives the estimates of surface temperature at the gas-based age ties shown in Table 2.

We generate a range of possible $\Delta$ age based on several accumulation rate constraints (see below). We then turn this range of 5 estimates into a single combined pdf for $\Delta$ age. This method overcomes previous uncertainties in the air-trapping, which arise from uncertainties in temperature and accumulation (Morgan et al., 2002; Pedro et al., 2011). 
Clim. Past Discuss., https://doi.org/10.5194/cp-2017-96

Manuscript under review for journal Clim. Past

Discussion started: 23 August 2017

(c) Author(s) 2017. CC BY 4.0 License.

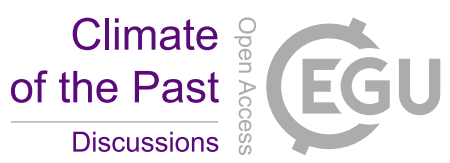

Table 2. Gas-based age ties used in the $\mathrm{LD} 2017$ timescale, and associated properties. Values are based on an isotopic slope of $0.44 \% 0^{\circ} \mathrm{C}^{-1}$ with values in parenthesis for an isotopic slope of $0.7 \% 0^{\circ} \mathrm{C}^{-1}$. Given the noisy nature of the $\mathrm{Ca}^{2+}$ measurements, have used the median value from within $0.5 \mathrm{~m}$ of the age tie.

\begin{tabular}{|c|c|c|c|c|c|c|c|c|c|}
\hline Depth & $\mathrm{y} b 2 \mathrm{k}$ & $\begin{array}{l}\text { Age } \\
\text { uncertainty }\end{array}$ & $\begin{array}{l}\text { Surface } \\
\text { temperature } \\
{ }^{\circ} \mathrm{C}\end{array}$ & $\begin{array}{l}\text { Vapour } \\
\text { pressue } \\
\text { accumulation } \\
\mathrm{my}^{-1} \text { ie }\end{array}$ & $\begin{array}{l}\text { Geothermal } \\
\text { ICE-5G(VM2) } \\
\text { accumulation } \\
\mathrm{my}^{-1} \text { ie }\end{array}$ & $\begin{array}{l}\text { Geothermal } \\
\text { W12 } \\
\text { accumulation } \\
\mathrm{my}^{-1} \text { ie }\end{array}$ & $\operatorname{ng~g}^{-1}$ & $\Delta$ age & $\begin{array}{l}\Delta \text { age } \\
\text { uncertainty }\end{array}$ \\
\hline 1101.137 & $8178^{a}$ & 30 & $-19.75(-20.59)$ & $0.699(0.711)$ & $0.228(0.208)$ & $0.220(0.201)$ & 3.34 & 107.8 & 50.0 \\
\hline 1101.772 & $8270^{a}$ & 30 & $-19.46(-20.40)$ & $0.734(0.715)$ & $0.238(0.215)$ & $0.227(0.205)$ & 3.83 & 104.1 & 48.3 \\
\hline 1108.640 & $9333^{b}$ & 150 & $-19.05(-20.14)$ & $0.743(0.720)$ & $0.253(0.225)$ & $0.238(0.211)$ & 1.72 & 103.0 & 46.9 \\
\hline 1121.290 & $11681^{c}$ & 75 & $-22.28(-22.17)$ & $0.676(0.678)$ & $0.194(0.196)$ & $0.196(0.199)$ & 2.59 & 121.8 & 57.8 \\
\hline 1125.190 & $12819^{d}$ & 102 & $-26.64(-24.92)$ & $0.595(0.626)$ & $0.134(0.154)$ & $0.147(0.169)$ & 5.19 & 156.8 & 83.8 \\
\hline 1129.040 & $14687^{e}$ & 30 & $-26.25(-24.67)$ & $0.602(0.630)$ & $0.141(0.161)$ & $0.172(0.196)$ & 4.21 & 147.7 & 75.6 \\
\hline 1138.482 & $28780^{f}$ & 74 & $-35.63(-30.57)$ & $0.454(0.530)$ & $0.078(0.104)$ & $0.091(0.126)$ & 15.63 & 254.4 & 162.4 \\
\hline 1144.280 & $35480^{g}$ & 184 & $-34.21(-29.68)$ & $0.474(0.543)$ & $0.083(0.109)$ & $0.097(0.130)$ & 5.88 & 244.9 & 152.0 \\
\hline 1146.700 & $38220^{h}$ & 197 & $-32.34(-28.50)$ & $0.501(0.563)$ & $0.091(0.119)$ & $0.108(0.141)$ & 14.57 & 211.9 & 128.7 \\
\hline
\end{tabular}

${ }^{a} 8.2 \mathrm{ky}$ bracket

${ }^{b} \delta^{18} \mathrm{O}$ air modern end transition hump (on GICC05)

${ }^{c} \mathrm{CH}_{4}$ YD to Holocene transition (GICC05)

${ }^{d} \mathrm{CH}_{4}$ BA to YD transition (GICC05)

${ }^{e} \mathrm{CH}_{4}$ Older Dryas to BA transition (GICC05)

${ }^{f} \mathrm{CH}_{4}$ DO4 transition (GICC05)

${ }^{g} \mathrm{CH}_{4}$ DO7 transition (GICC05)

${ }^{h} \mathrm{CH}_{4}$ DO8 transition (GICC05)

\subsection{Accumulation constraints}

To estimate the pdf for the $\Delta$ age offset for gas-based age ties, estimates of palaeo-accumulation are required. To allow for uncertainties to propagate fully through the age model, we use two estimates of accumulation, providing a lower and upper bound on likely accumulation rates.

5 We estimate an upper bound on the accumulation rate (Table 2) using the method of Jouzel et al. (2003) to account for changes in the atmospheric saturation vapour pressure. Specifically, the modern accumulation is scaled by the ratio of the temperature derivative of the saturation vapour pressure evaluated at the historical conditions compared to modern conditions. We use the saturation vapour pressure formulation of Murphy and Koop (2005) which is accurate to within $0.025 \%$ for temperatures greater than $-163{ }^{\circ} \mathrm{C}$. The strength of the atmospheric temperature inversion $\left(T_{i n v}\right.$ in $\left.{ }^{\circ} \mathrm{C}\right)$ is

$10 T_{\text {inv }}=T_{\text {surf }}+1.0+0.67\left(T_{\text {surf }}-T_{\text {surf }, \text { modern }}\right)$, 
Clim. Past Discuss., https://doi.org/10.5194/cp-2017-96

Manuscript under review for journal Clim. Past

Discussion started: 23 August 2017

(c) Author(s) 2017. CC BY 4.0 License.

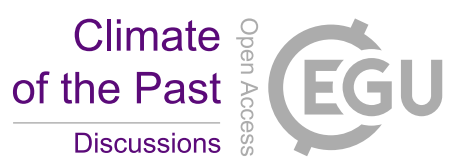

where $T_{\text {surf }}$ is the estimated surface temperature $\left({ }^{\circ} \mathrm{C}\right)$ at the time under consideration, $T_{\text {surf,modern }}$ the modern surface temperature $\left({ }^{\circ} \mathrm{C}\right.$ ), the factor of 0.67 is the ratio of changes in inversion strength to surface temperature (Jouzel et al., 1987) and the offset of $1.0^{\circ} \mathrm{C}$ is the estimated modern inversion strength (van Ommen et al., 2004).

The geothermal heat flux at the site provides an lower bound on accumulation rate (Table 2). Specifically, an accumulation 5 rate below this lower bound would result in insufficient advection of cold from the surface to counteract the geothermal heat flux, leading to basal melting, which can be seen not to have occured in the past, as relict ice from the last interglacial or earlier remains at the base of the icesheet (Morgan et al., 1997).

We assume that the temperature $\left(T_{B}\right.$ in $\left.{ }^{\circ} \mathrm{C}\right)$ at the base of the ice sheet is at the (ice thickness dependant) melting point, and the surface $\left(T_{S}\right.$ in $\left.{ }^{\circ} \mathrm{C}\right)$ at the temperature estimated from the water isotope record (Table 2). We then calculate the accumulation rate required to maintain this temperature difference. Specifically, using ice sheet thickness $(z$ in $\mathrm{m}$ ) from two independent reconstructions, ICE-5G(VM2) (Peltier, 2004) and W12 (Whitehouse et al., 2012a), the basal temperature (melting point) is taken as $T_{B}=0.01-8.7 \times 10^{-4} z$ (Paterson, 1994, Chapter 10). This excludes the influence of impurities, which tend to depress the melting point and hence the accumulation values would need to be larger to compensate for this. Therefore as a lower bound, excluding this effect is conservative.

The temperature differential between the surface and base of the ice sheet can be estimated from the near divide steady state temperature equation (Paterson, 1994, pages 216-220), viz:

$\theta_{B}=\left[\frac{\pi}{2 \gamma} \operatorname{erf}\left(\frac{\gamma}{2}\right)\right]^{0.5}$

where $\theta_{B}=\frac{K\left(T_{B}-T_{S}\right)}{G h}$ is the dimensionless temperature difference, $\gamma=\frac{a z}{\kappa}$ is the Peclet number, $a$ is accumulation $\left(\mathrm{m} \mathrm{y}^{-1}\right.$ ie), $G$ is geothermal heat flux $\left(72 \mathrm{~mW} \mathrm{~m}^{-2}\right.$, van Ommen et al. 1999), thermal conductivity $K=9.828 \exp \left(-5.7 \times 10^{-3}(T+273.15)\right)$

$20\left(\mathrm{~W} \mathrm{~m}^{-1} \mathrm{~K}^{-1}\right), \kappa=\frac{K}{\rho C}$ is the thermal diffusivity $\left(\mathrm{m}^{2} \mathrm{~s}^{-1}\right)$, and the specific heat $C=152.5+7.122(T+273.15)\left(\mathrm{J} \mathrm{kg}^{-1} \mathrm{~K}^{-1}\right)$.

As per Whitehouse et al. (2012b) we have assumed a constant ice sheet thickness between 30 and $20 \mathrm{ky}$, and a linear change between present ice sheet thickness at $100 \mathrm{ky}$ and $30 \mathrm{ky}$.

To simplify the calculations we replace the error function with a rational function approximation (Abramowitz and Stegun, 1968) valid for $x \geq 0$,

$25 \operatorname{erf}(x)=1-\left(0.3480242 y-0.0958798 y^{2}+0.7478556 y^{3}\right) e^{-x^{2}}$,

where $y=\frac{1}{1+0.47047 x}$ and evaluate for accumulation rate $(a)$ to ensure basal temperature above the local melting point.

\section{4 $\Delta$ age offset}

The age offset for the gas-based age ties can be estimated using firn densification models. Again, to fully propagate uncertainties throughout the age model, we use firn densification models both with and without impurity effects to estimate the sensitivity of our results to these factors.

The $\Delta$ age is calculated using the steady state Pimienta firn densification model (Barnola et al., 1991), which is known to work well (Ligtenberg et al., 2011), using the modification of Freitag et al. (2013) to account for the effects of surface impurity 
Clim. Past Discuss., https://doi.org/10.5194/cp-2017-96

Manuscript under review for journal Clim. Past

Discussion started: 23 August 2017

(c) Author(s) 2017. CC BY 4.0 License.

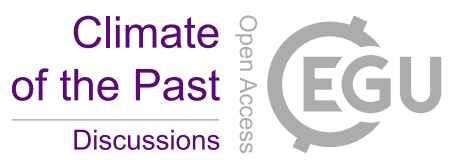

(c) (i)

content (specifically through the $\mathrm{Ca}^{2+}$ concentration, see Table 2), and a bubble close off at a firn density of $830 \mathrm{~kg} \mathrm{~m}^{-3}$ (Freitag et al., 2013). Surface snow density is calculated using the formulation of Kaspers et al. (2004), allowing for an Antarctic slope correction as per Helsen et al. (2008) and a surface wind speed of $8.3 \mathrm{~m} \mathrm{~s}^{-1}$ (Morgan et al., 1997).

In addition to the bubble close off depth (and associated firn age) calculated above, atmospheric gases diffuse in the firn.

5 Therefore, we need to correct $\Delta$ age for this effect, which we do using the method of Spahni et al. (2003); Etheridge et al. (1998); Trudinger et al. (1997). This correction is subtracted from $\Delta$ age, and the uncertainties combined assuming independence. We ignore the spread of air age in the ice for the uncertainty calculations.

Subtracting the gas diffusion ages from the firn cut-off age estimates gives an $\Delta$ age estimate for how much older the ice is compared to the mean age of the air in the ice the same depth. The firn cut off estimate is the weighted average of the

10 lower and upper bound. The eight lower bound estimates are based on geothermal heat flux (two isotope slopes, two thickness reconstructions, and with and without the influence of $\mathrm{Ca}^{2+}$ ). The corresponding four upper bound estimates age based on the saturation vapour pressure (two isotope slopes, and with and without the influence of $\mathrm{Ca}^{2+}$ ). To minimise biasing towards the lower bound, these estimates were weighted by a factor of 0.5 . The resulting $\Delta$ age estimates and associated uncertainties are shown in Table 2 and the full list of age ties is given in Table 3.

\subsection{Thickness data}

To further constrain the age model and reduce age uncertainties (see Section 5) we included one spot annual layer thickness data measurement from Roberts (1999) of $0.046 \mathrm{~m} \mathrm{y}^{-1}$ at a depth of $1038.22 \mathrm{~m}$ based on $19 \mathrm{y}$ of high resolution isotope measurements from the analysis core DSS 1091. (Note, the depth of this core has previously been revised to a slightly greater depth than reported in Roberts 1999).

20 The standard deviation associated with layer thickness measurements was estimated from the ratio of the mean to standard deviation in the Law Dome accumulation record for 19 y moving windows over the 2 ky accumulation record of Roberts et al. (2015).

\section{Age interpolation models}

The method of van Ommen et al. (2004) used the vertical strain rate and velocity profile calculated from fitting a Dansgaard and Johnsen (1969) profile to age ties. In particular, vertical velocity (or annual layer thickness) offsets were introduced between ties to account for discrepancies in modelled ages within the inter-tie point zones. This results in step changes in annual accumulation what are physically unrealistic. Furthermore, the use of a vertical strain rate profile with a smooth first derivative is internally inconsistent, as any step change in accumulation should distort the vertical strain rate profile.

The method used here involved piece-wise fitting a continuous linear vertical velocity profile. Specifically, a piece-wise 30 parabolic annual layer thickness model is used, which is equivalent to a piece-wise linear vertical strain rate, a piece-wise parabolic annual accumulation rate or any combination of the two. With such a scheme any change in vertical velocity (or equivalently annual accumulation rate) is therefore smooth. It is similar to the ALT model of Fudge et al. (2014) although with 
Clim. Past Discuss., https://doi.org/10.5194/cp-2017-96

Manuscript under review for journal Clim. Past

Discussion started: 23 August 2017

(c) Author(s) 2017. CC BY 4.0 License.

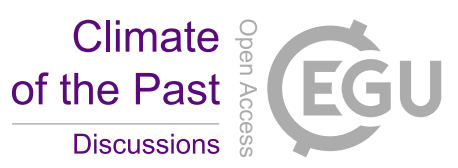

(c) (i)

Table 3. Age ties, uncertainties in depth and age are 2 standard deviations except for the upper two ages (which are 3 standard deviations). $\Delta$ age uncertainties are one standard deviation.

\begin{tabular}{|c|c|c|}
\hline Depth m & age $y$ & $\Delta$ age $\mathrm{y}$ \\
\hline $761.020 \pm 0.010$ & $1856+4 /-7$ & \\
\hline $852.668 \pm 0.010$ & $2332+15 /-8$ & \\
\hline $868.16 \pm 0.010$ & $2438.48 \pm 20$ & \\
\hline $949.32 \pm 0.010$ & $3374.83 \pm 20$ & \\
\hline $951.98 \pm 0.010$ & $3421.48 \pm 20$ & \\
\hline $952.6 \pm 0.010$ & $3431.33 \pm 20$ & \\
\hline $966.49 \pm 0.010$ & $3675.96 \pm 20$ & \\
\hline $970.31 \pm 0.010$ & $3735.52 \pm 20$ & \\
\hline $987.43 \pm 0.010$ & $4053.86 \pm 20$ & \\
\hline $1101.137 \pm 0.010$ & $8178 \pm 30$ & $107.8 \pm 50.0$ \\
\hline $1101.772 \pm 0.030$ & $8270 \pm 30$ & $104.1 \pm 48.3$ \\
\hline $1108.640 \pm 0.100$ & $9333 \pm 150$ & $103.0 \pm 46.9$ \\
\hline $1121.290 \pm 0.010$ & $11681 \pm 75$ & $121.8 \pm 57.8$ \\
\hline $1125.190 \pm 0.100$ & $12819 \pm 102$ & $156.8 \pm 83.8$ \\
\hline $1129.040 \pm 0.100$ & $14687 \pm 30$ & $147.7 \pm 75.6$ \\
\hline $1130.895 \pm 0.010$ & $16630 \pm 328$ & \\
\hline $1132.220 \pm 0.010$ & $18618 \pm 328$ & \\
\hline $1138.482 \pm 0.010$ & $28780 \pm 74$ & $254.4 \pm 162.4$ \\
\hline $1144.280 \pm 0.010$ & $35480 \pm 184$ & $244.9 \pm 152.0$ \\
\hline $1146.700 \pm 0.010$ & $38220 \pm 197$ & $211.9 \pm 128.7$ \\
\hline $1156.082 \pm 0.010$ & $48112 \pm 1000$ & \\
\hline $1164.717 \pm 0.010$ & $60312 \pm 1000$ & \\
\hline $1170.452 \pm 0.010$ & $72212 \pm 2000$ & \\
\hline $1172.792 \pm 0.010$ & $75812 \pm 2000$ & \\
\hline $1179.542 \pm 0.010$ & $84012 \pm 2000$ & \\
\hline $1182.302 \pm 0.010$ & $88012 \pm 2000$ & \\
\hline
\end{tabular}

greater annual layer thickness discontinuity, which we attempt to minimise. Due to the rapid change in the depth derivative of layer thicknesses around $8.2 \mathrm{ky}$, a piece-wise parabolic model was fitted to either side of the $8.2 \mathrm{ky}$ event, and a linear annual layer thickness model was used to span the $8.2 \mathrm{ky}$ event. The piece-wise parabolic model only approximately passes through the age ties (in a least squares sense), and a small linear correction is applied between age ties to ensure the model matches the 5 target age ties. 
Clim. Past Discuss., https://doi.org/10.5194/cp-2017-96

Manuscript under review for journal Clim. Past

Discussion started: 23 August 2017

(c) Author(s) 2017. CC BY 4.0 License.

For two ties at depth $z_{1}$ and $z_{2}$, separated in time by $\Delta t$ and with a local annual layer thickness $L(z)=a z^{2}+b z+c$, the age difference $\left(\Delta t^{\prime}\right)$ between the ties is

$\Delta t^{\prime}=\int_{z_{1}}^{z_{2}} \frac{1}{a z^{2}+b z+c} d z$

where $\Delta t \sim \Delta t^{\prime}$ for a good estimate. The evaluation of the integral is given by Gradshteyn and Ryzhik (1980, Section 2.172).

5 The values of $a, b$ and $c$ are directly related to the estimated annual layer thicknesses at (the subset of) age ties. Particle swarm optimisation (Pedersen and Chipperfield, 2010; Roberts et al., 2013) was used to optimise the layer thicknesses and minimise the cost function,

$C F=\sum_{2}^{n}\left(\left[\Delta t-\Delta t^{\prime}\right]^{2}+\lambda[\Delta \text { correction }]^{2}\right)$,

where the summation starts at the second age tie, because all ages in this model are relative, and are taken with reference to the upper age tie. A change in linear correction across an age tie ( $\Delta$ correction) is added to ensure that the model passes exactly through the surrounding age ties. Changes in this correction result in discontinuities in the annual layer thickness model, which we minimise. The optimisation was robust to a wide range of the relative weighting parameter $\lambda$ and a value of 25.0 was used.

To avoid over-fitting only a subset of age ties were used directly in the particle swarm optimisation, but all age ties had to be honoured through appropriate linear corrections. In particular, five age ties above the 8.2 ky event and seven below were used, with the choice of the number of segments based on a generalised cross-validation analysis (Friedman and Silverman, 1989).

Particle swarm optimisation may focus on a local optima and fail to find a global optimum. To alleviate this behaviour, the particle swarm optimisation was restarted 1,000 times with random initial conditions to ensure good coverage of the parameter space, and each restart randomly selected which age ties would be used to define the parabolic segments.

\section{Ensemble models of age scale}

To allow for the computation of not only the median age model consistent with the age ties, but to also quantify the uncertainty in the age model, an ensemble approach was used. Specifically, 10,000 realisations of possible age tie sets were randomly generated from the probability density functions associated with both the depth and age of each age tie. The upper two ties (annual layer counting), have non-symmetric errors, so skew normal distributions with zero median (see Figure 1) were generated using the method of Ashour and Abdel-hameed (2010). The $1856 \mathrm{~b} 2 \mathrm{k}$ age tie required a skew parameter of 3.73 to reproduce the $95 \%$ certainty interval of $-7 /+4 \mathrm{y}$. The corresponding data for the $2332 \mathrm{y} \mathrm{b2k}$ age tie was a skew parameter of 4.68 for the $-8 /+15$ y interval. For all other ties, symmetric normal distributions with a 2 sigma error specified in Table 3 were used. The age and $\Delta$ age uncertainties were handled independently and then combined to produce a target age. Due to the relatively close spacing of the age ties relative to their corresponding uncertainty, some of the random ensemble members have the order of age ties swapped, and must rejected.

The lack of a tie point between the depths of 987.43 and $1101.137 \mathrm{~m}$ results in excessive uncertainty in the age model in this region (approximately 5.5 times greater than the results presented here). To alleviate this, we include the layer thickness data 
Clim. Past Discuss., https://doi.org/10.5194/cp-2017-96

Manuscript under review for journal Clim. Past

Discussion started: 23 August 2017

(c) Author(s) 2017. CC BY 4.0 License.

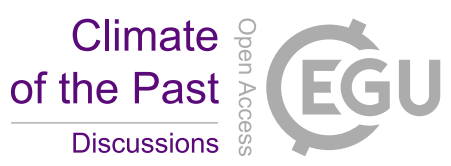

(c) (i)

of Roberts (1999) to further constrain the model. Any particle swarm optimisation solution that resulted in a layer thickness at 1038.22 m outside 3 standard deviations of the measurement of Roberts (1999) was rejected.

An age model was generated for each ensemble member, and the median and uncertainty for each model year calculated for the entire ensemble. These results are presented in Figures 2-3. For the robust calculation of uncertainty, assuming a normal 5 distribution, we approximate the standard deviation as 1.4826 times the difference between the $75^{\text {th }}$ and $25^{\text {th }}$ percentile. Uncertainty in depth for a given year is the primary uncertainty calculated. This is mapped into an age uncertainty by averaging the age offsets before and after a point required to achieve a median depth offset by the depth standard deviation.

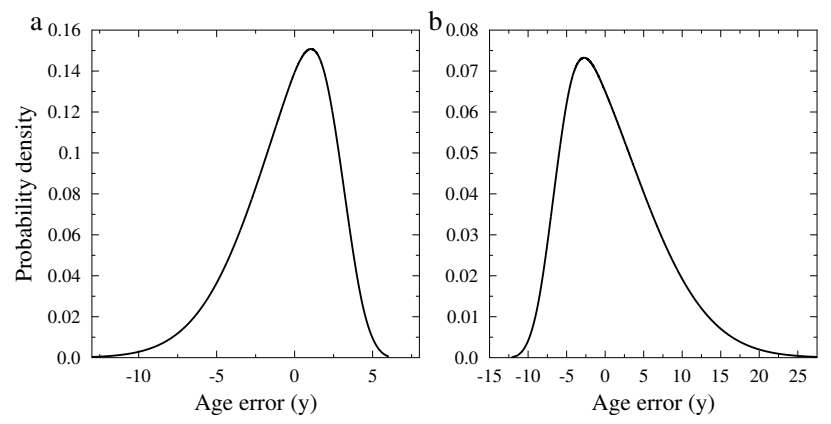

Figure 1. Probability density function for annual layer counted age ties a) 1856 y b2k and b) 2332 y b2k

\section{Discussion}

This updated age model for the Law Dome DSS ice core (Figure 2) is characterised by a break in slope at around $1110 \mathrm{~m}$ depth, the result of either a change in accumulation regime from high to low, a major change in the vertical strain rate or some combination of the two. A key feature of this age model is the use of gas-based age ties using independent estimates of accumulation, rather than estimating the accumulation rate within the model at the same time. This aids in reducing uncertainties in the age model, along with layer thickness data used to further constrain the model. The uncertainty in depth (and hence age) increases further back in time, as shown in Figure 3, with larger uncertainties occurring between the gas-based age ties. We discuss some of these factors, using annually counted layers in Section 6.1 and ties with past recorded volcanic events in Section 6.2. We further discuss the consistency of this age model with independent estimates for the accumulation rate from the various sources in Section 6.4. Finally, in Section 6.5 we give an overview of the ice dynamics used by this model to draw a connection between ice flow and the thickness of internal layers within the ice core.

\subsection{Age model comparison with annually counted layers}

20 It is possible to investigate the fidelity of the age uncertainties generated through the Monte Carlo ensemble approach of Section 5. Specifically between the upper two age ties we have an independent age scale from annual layer counting based on water stable isotope and chemistry species variations. Figure 4 presents the differences in the age depths for these two 
Clim. Past Discuss., https://doi.org/10.5194/cp-2017-96

Manuscript under review for journal Clim. Past

Discussion started: 23 August 2017

(c) Author(s) 2017. CC BY 4.0 License.

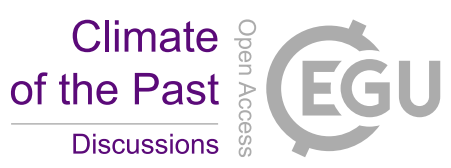

(c) (i)

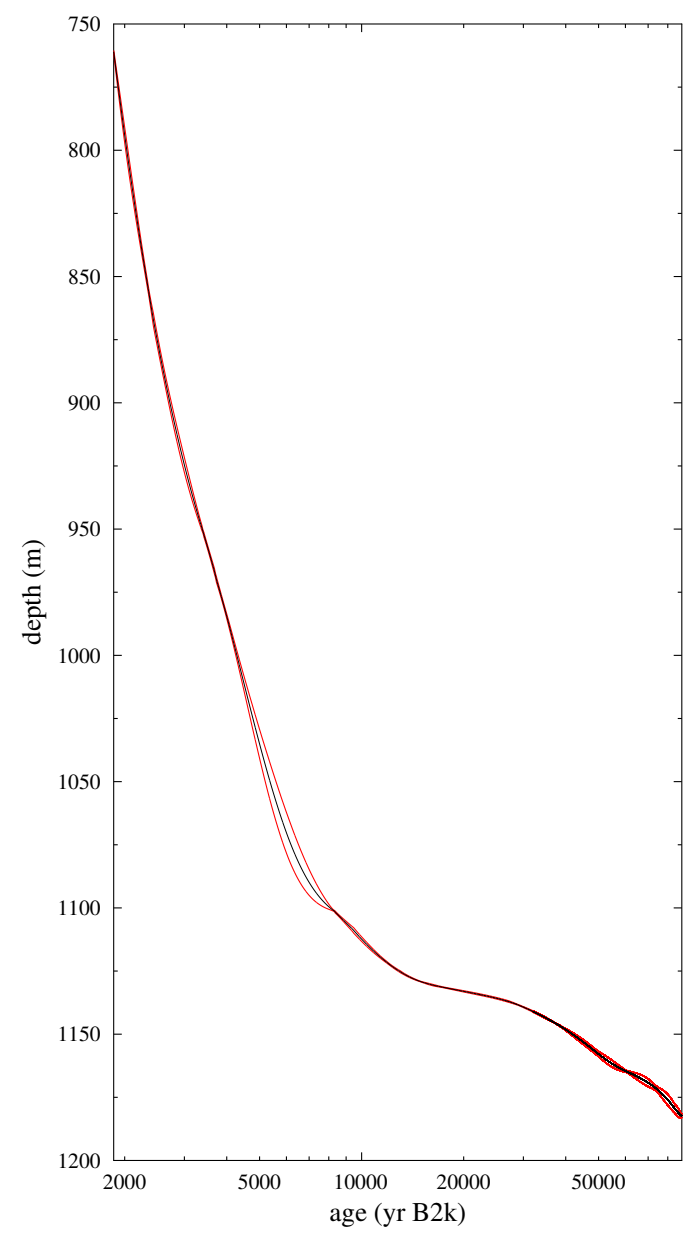

Figure 2. LD2017 Age model for the DSS ice core. Black line is median of 10,000 member ensemble while red curves show \pm 1 standard deviation from this median.

age scales. Differences are within the age model uncertainty, except for 6 years between 2211-2234 y b2k. The maximum discrepancy is around $2.2 \mathrm{~m}$, with uncertainty reducing with increasing proximity to an age tie, as expected. 
Clim. Past Discuss., https://doi.org/10.5194/cp-2017-96

Manuscript under review for journal Clim. Past

Discussion started: 23 August 2017

(c) Author(s) 2017. CC BY 4.0 License.

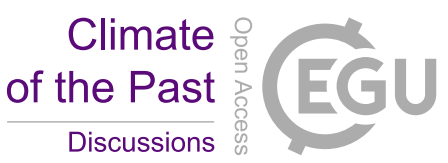

(c) (i)

a)

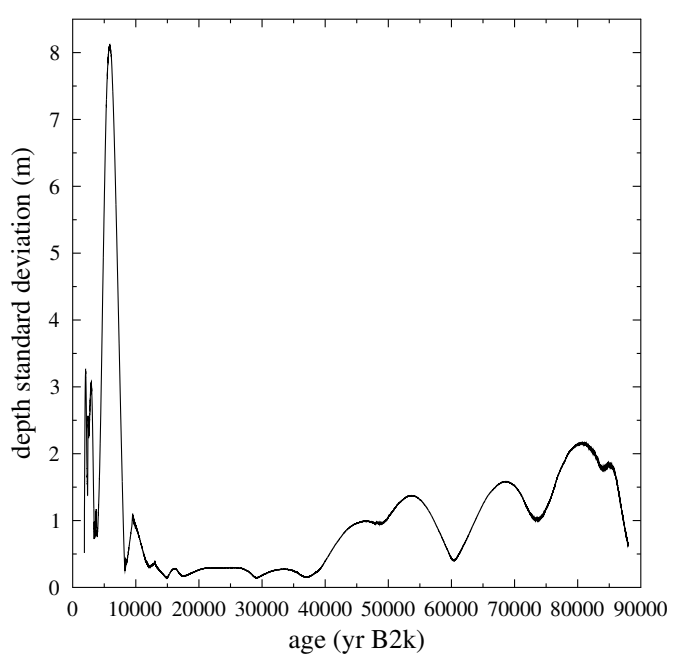

b)

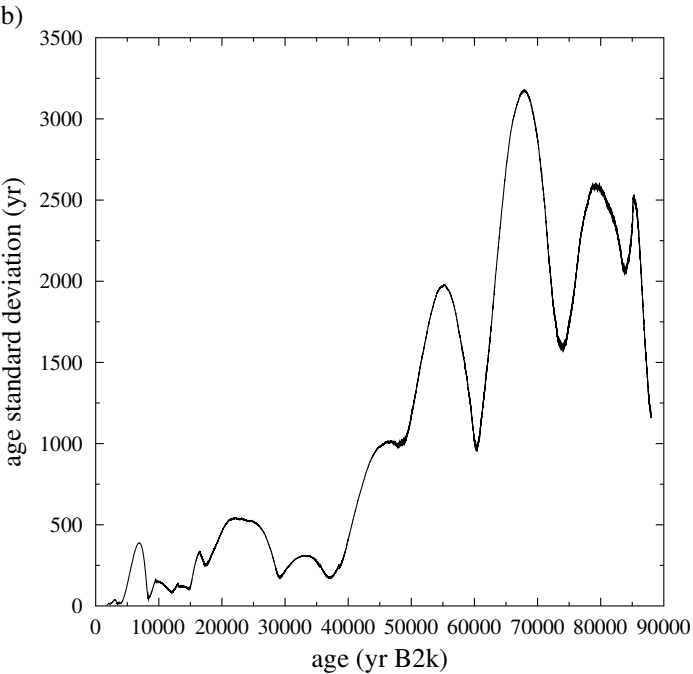

Figure 3. Standard deviation in a) depth and b) age as a function of median age for DSS age model.

The major source of uncertainty is associated with the pdfs of each age tie, with no direct information available between ties to further constrain the model (with the exception of the thickness constraint discussed in Section 3.5). The parabolic accumulation variation that the age model allows is based on longer epochs encompassing at least 3 age ties, and is incapable of directly resolving any non-linear variations that last for less than the time between age ties. Therefore, while the age model

5 allows for parabolic variations in accumulation, it is not surprising that it fails to capture the approximately parabolic discrepancy shown in Figure 4, as this variation is at a higher frequency than the model is able to resolve. However, it is encouraging 
Clim. Past Discuss., https://doi.org/10.5194/cp-2017-96

Manuscript under review for journal Clim. Past

Discussion started: 23 August 2017

(c) Author(s) 2017. CC BY 4.0 License.

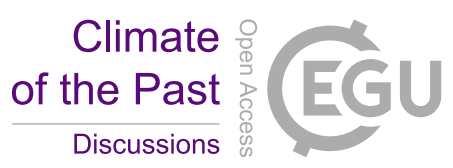

(c) (i)

that the uncertainty (estimated to approximate a \pm 1 standard deviation, i.e. encompassing $\sim 68.3 \%$ of the data) covers $97.5 \%$ of the data.

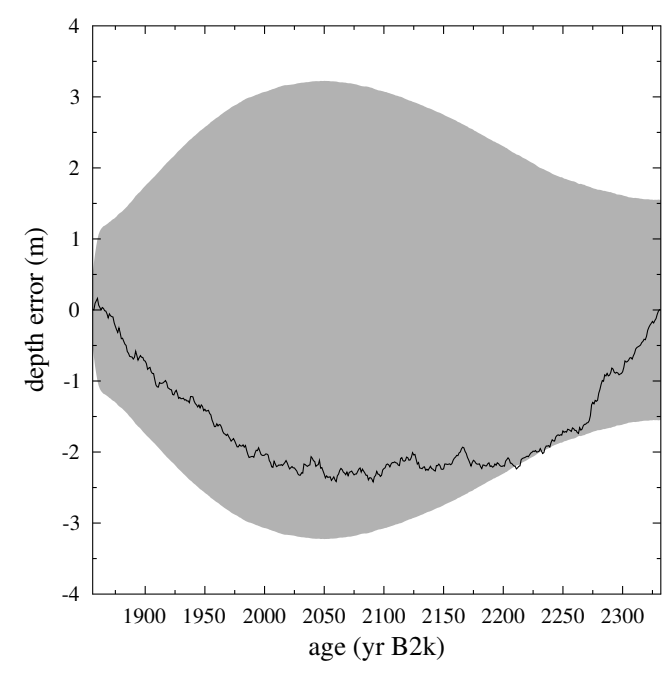

Figure 4. Difference in depth between the age model and the annually counted region for ages between 1856-2332 y b2k. Gray shading shows the calculated depth uncertainty for any given year.

\subsection{Volcanic verification points}

Volcanic events recorded in the DSS non-sea-salt sulphate record were matched with those in the EDC99 dielectric profiling 5 (DEP) record (Parrenin et al., 2012) on the AICC2012 timescale (Veres et al., 2013) to determine common age horizons. Matches were made by comparison of the pattern and distribution of volcanic peaks, with 15 common events identified between 2332 and $5000 \mathrm{yb} 2 \mathrm{k}$. Poor quality ice led to a discontinuous DSS sulphate record from 5-7 y b2k, precluding any definitive matches during that period. From the 15 volcanic events identified, 7 used in the construction of the AICC2012 timescale were adopted as age ties between AICC2012 and DSS. The remaining volcanic events were used to compare the age model output to AICC2012 ages (Table 4). The model produces ages close to the AICC2012 timescale with a maximum 8-year difference, which is well within the dating uncertainty during this tightly-constrained time period.

\subsection{Previous age model}

The new LD2017 age scale derived here differs slightly from the LD1 scale which was used in a study of the timing of deglacial events at Law Dome (Pedro et al., 2011). In order to assess any impacts upon the conclusions around deglacial timing at Law Dome, we show in Figure 5 the depth-age relationship for both age models and the difference between the two (in both cases 
Clim. Past Discuss., https://doi.org/10.5194/cp-2017-96

Manuscript under review for journal Clim. Past

Discussion started: 23 August 2017

(c) Author(s) 2017. CC BY 4.0 License.

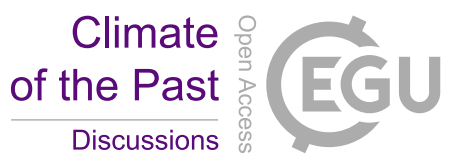

Table 4. Comparing DSS model and AICC2012 ages of common volcanic event horizons in DSS and EDC99 cores.

\begin{tabular}{lllll}
\hline $\begin{array}{l}\text { DSS Depth } \\
\mathrm{m}\end{array}$ & $\begin{array}{l}\text { EDC99 Depth } \\
\mathrm{m}\end{array}$ & $\begin{array}{l}\text { AICC2012 age } \\
\mathrm{y} \mathrm{b2k}\end{array}$ & $\begin{array}{l}\text { Modelled age } \\
\mathrm{y} \mathrm{b2k}(\text { difference) }\end{array}$ & $\begin{array}{l}\text { Uncertainty } \\
\mathrm{y}\end{array}$ \\
\hline 881.00 & 99.75 & 2540 & $2543(+3)$ & 20 \\
888.02 & 101.63 & 2603 & $2605(+2)$ & 21 \\
898.16 & 104.73 & 2703 & $2701(-2)$ & 25 \\
964.75 & 132.48 & 3637 & $3645(+8)$ & 18 \\
965.05 & 132.80 & 3648 & $3651(+3)$ & 18 \\
972.46 & 136.42 & 3770 & $3776(+6)$ & 18 \\
983.81 & 142.80 & 3988 & $3987(-1)$ & 17 \\
985.52 & 143.50 & 4013 & $4018(+5)$ & 18 \\
\hline
\end{tabular}

the abscissae are the LD1 ages shifted from before 1950 to b2k). It can be seen that the LD2017 age scale closely follows the LD1 scale, but exhibits smooth variation rather than the quasi-linear segments and inflection points of LD1. LD2017 uses essentially the same tie points as LD1, (with minor refinements), but with two exceptions. LD2017 adopts two new ties from the dust peak and trailing edge (as discussed earlier) and omits the poorly characterized 'mid-point' methane rise at LD depth 51131.75 m, ice-age 16.14 ky b2k (Pedro et al., 2011, Table 2).

The principal difference with the LD2017 age scale is that events around the late glacial occur significantly earlier: up to around $1.3 \mathrm{ky}$ at $19 \mathrm{ky}$ and $879 \mathrm{y}$ earlier at the onset of deglaciation as identified in Pedro et al. (2011). That is, the deglacial warming trend identified by Pedro as commencing at $17.89 \pm 0.32 \mathrm{ky} \mathrm{b} 2 \mathrm{k}$ is seen to occur at $18.76 \pm 0.35 \mathrm{ky} b 2 \mathrm{k}$. This earlier onset is actually more consistent with the timing $19.03 \pm 0.50 \mathrm{ky} \mathrm{b} 2 \mathrm{k}$ that is seen in the composite of other high resolution records (Pedro et al., 2011).

From the early deglacial, the timescale differences decrease, with coincidence around $15.44 \mathrm{ky} \mathrm{b2 \textrm {k }}$. From this point, through the set of essentially common ties between the two age scales the LD2017 ages are slightly younger: principally because the new method estimates smaller $\Delta$ age values. Thus, the earliest onset of the Antarctic Cold Reversal (ACR), as identified by

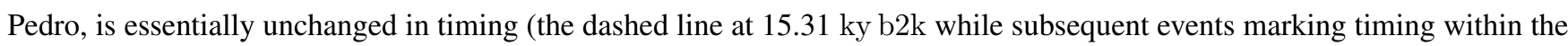
ACR window are up to around 270 years later. At the end of deglacial warming (ca. $9.7 \mathrm{ky} \mathrm{b2k}$ the two age scales are once again within error estimates.

\subsection{Accumulation estimates}

A key variable in estimating the ice-based age associated with gas-based age ties is the accumulation rate. Here we present several independent estimates to check for broad consistency with the results shown in Table 2.

The age model of van Ommen et al. (2004) provided accumulation estimates for the interval either side of the age tie simultaneously. In general, we show good agreement with these estimates (Fig. 6) during the Holocene, although we have a 
Clim. Past Discuss., https://doi.org/10.5194/cp-2017-96

Manuscript under review for journal Clim. Past

Discussion started: 23 August 2017

(c) Author(s) 2017. CC BY 4.0 License.

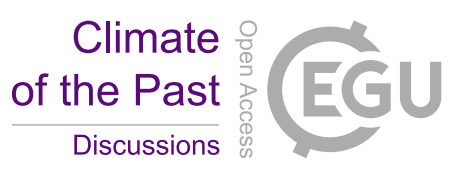

(c) (i)

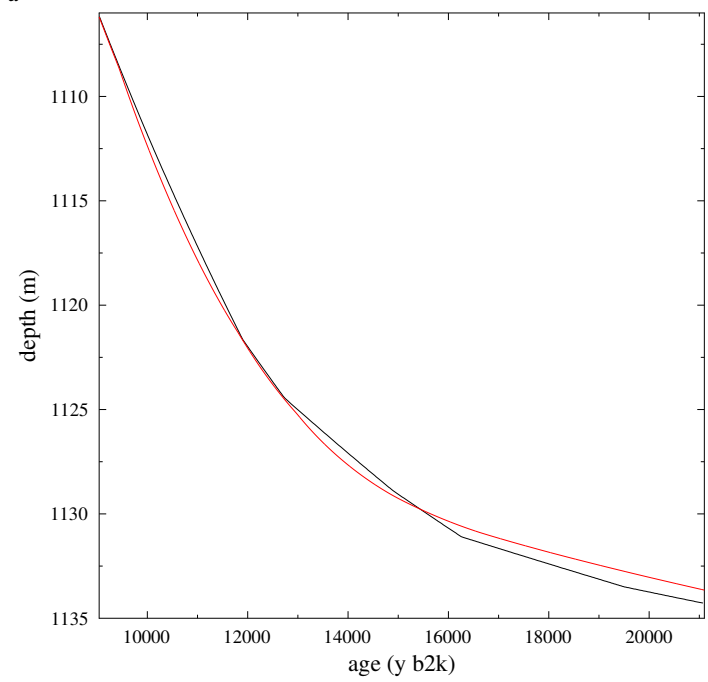

b

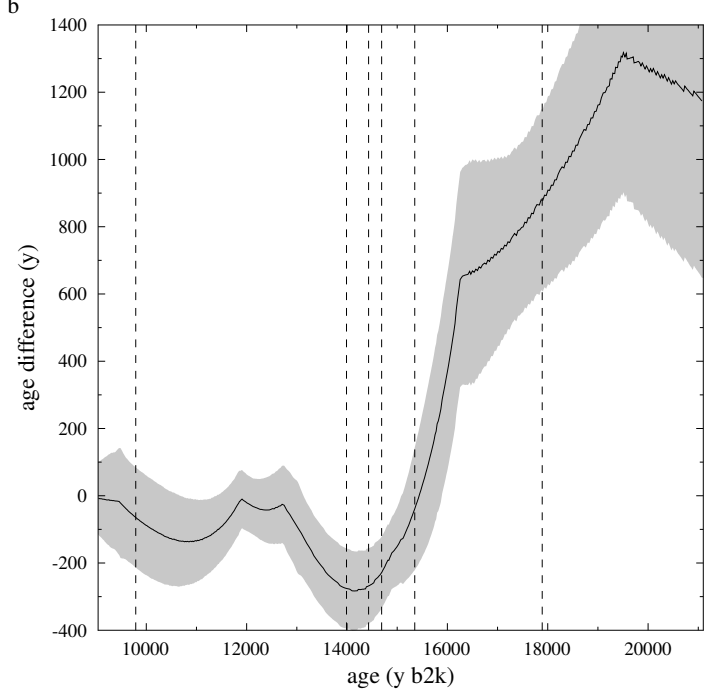

Figure 5. a) omparision of LD2017 (red) with the age model of Pedro et al. (2011) (black) over the deglaciation. b) Difference between LD2017 and Pedro et al. (2011) (black) and uncertainty in age from LD2017 (gray shading). Also shown are the timing of climate features from Pedro et al. (2011) (dashed lines) at 9.79, 13.99, 14.43, 14.69, 15.35 and $17.89 \mathrm{ky}$.

consistently higher accumulation rate around the last glacial maximum. During the last glacial maximum, the accumulation estimates of van Ommen et al. (2004) are lower than the lower bound required to avoid basal melt from the geothermal heat flux. As any such melt is absent at DSS, we conclude that the estimates of van Ommen et al. (2004) may be too low.

Due to differences in methodology, any discrepancies in ice flow physics and dating in van Ommen et al. (2004) will require 
Clim. Past Discuss., https://doi.org/10.5194/cp-2017-96

Manuscript under review for journal Clim. Past

Discussion started: 23 August 2017

(c) Author(s) 2017. CC BY 4.0 License.

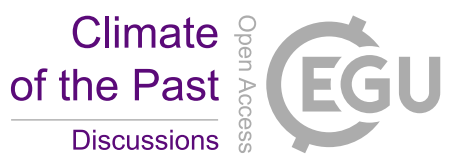

(c) (i)

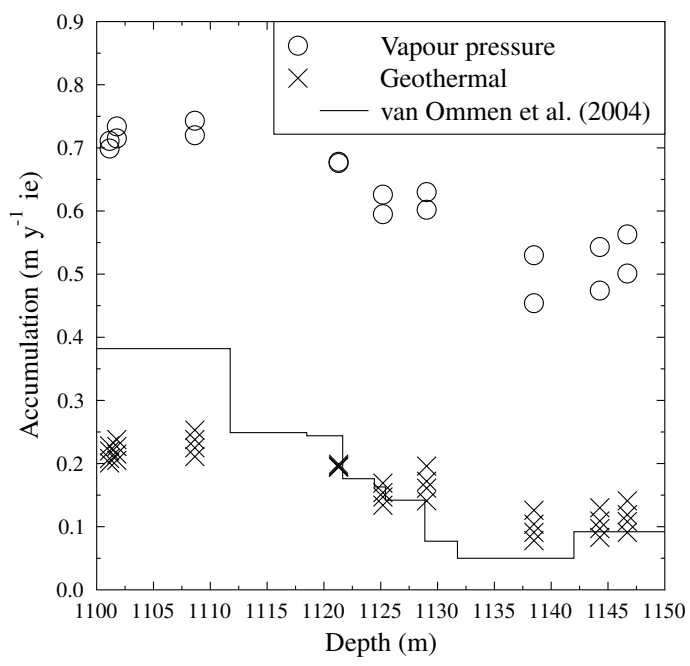

Figure 6. Accumulation (Table 2 upper bound (based on saturation vapour pressure) and lower bound (based on geothermal heat flux) compared to the previous estimates of van Ommen et al. (2004).

Holocene to last glacial maximum accumulation rate at Vostok is around 1.8 (Siegert, 2003). The associated upper bound on the accumulation rate at DSS during the last glacial maximum is $0.372 \mathrm{~m}$ ice eq. $\mathrm{y}^{-1}$, again consistent with our results.

Based on firn lock-in depths calculated from $\Delta^{15} N$ gas analysis and subsequent firn densification modelling, Landais et al. (2006) estimates LGM accumulation as $0.025-0.06 \mathrm{~m}_{\text {eq ice }} \mathrm{y}^{-1}$ and temperature between -37 and $-32{ }^{\circ} \mathrm{C}$. This is somewhat

5 lower than our estimates, but within $0.02 \mathrm{~m} \mathrm{eq} \mathrm{ice}^{-1}$ of our geothermal-based lower bound. The relatively high accumulation rate at DSS might be a contributing factor here as many firn densification models are optimised for lower accumulation rates.

An estimate of the Holocene to last glacial maximum accumulation rate change can be made based on the relative dust concentration in the DSS ice core. van Ommen et al. (2004) used the relative dust concentrations at Holocene and last glacial maximum for both the DSS and Vostok ice cores to suggest an approximate 7-8 times variation in accumulation rate between the Holocene and last glacial maximum. This would suggest a last glacial maximum accumulation rate of around $0.09 \mathrm{~m} \mathrm{eq} \mathrm{ice}^{-1}$, broadly consistent with our lower bound (Fig. 6). It should be noted that there is significant uncertainty in this estimate due to very low dust concentrations at DSS.

\subsection{Ice Dynamics}

In determining this age model for Law Dome we have avoided drawing a direct connection between the thickness of internal layers and the corresponding accumulation rate. The former are strongly influenced by the local ice dynamics, which become increasingly complex towards the base of the ice sheet. The horizontal velocity profile at the DSS site (Figure 7) has been 
Clim. Past Discuss., https://doi.org/10.5194/cp-2017-96

Manuscript under review for journal Clim. Past

Discussion started: 23 August 2017

(c) Author(s) 2017. CC BY 4.0 License.

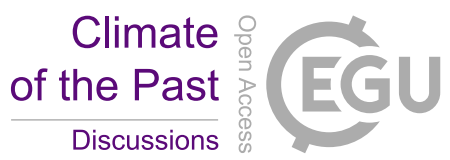

determined from repeat measurements of the borehole inclination (Morgan et al., 1998). For a height above the bed $\gtrsim 160 \mathrm{~m}$ the measured horizontal velocities are well described by a calculated profile (Figure 7), determined by fitting to the horizontal velocity shape function (Lliboutry, 1979). Specifically,

$v=2.134 *\left(1-\left(1-\frac{h-74.27}{1178.47-74.27}\right)^{3.178+1}\right)$,

5 where $v$ is the velocity $\left(\mathrm{m} \mathrm{y}^{-1}\right)$ and $h$ the height above bedrock $(\mathrm{m})$. However, for heights $\lesssim 160 \mathrm{~m}$ above the bed the measured and calculated profiles diverge due to the influence of undulations in the bed topography on the ice flow. The associated inflection in the velocity profile is consistent with those encountered in boundary layer flows where an adverse pressure gradient exists. Specifically, adverse pressure gradients are associated with velocity profiles where the reduction in velocity at depths close to the bed is greater than that expected in the case of neutral or favourable pressure gradient (e.g. Schlichting, 1968). Similar inflections in the lower sections of the velocity profiles, in response to an adverse pressure gradient, have been observed at other sites on Law Dome (Etheridge, 1989). This indicates that the profile at the DSS site does not result from a unique set of dynamic conditions; rather such profiles are a ubiquitous consequence of flow over undulating topography, and maybe futher enhanced by the increased impurity content of the ice at these depths. Furthermore, experimental and analytical studies demonstrate that for creeping flows over undulating surfaces there are two distinct zones. There is a lower zone of disturbed flow whose thickness varies spatially according to the amplitude and wavelength of the undulations. Above this zone there is a region where the only influence of the undulating boundary on the velocity profile is a vertical displacement of its virtual origin (Wierschem et al., 2003; Scholle et al., 2004), a displacement of $\sim 74 \mathrm{~m}$ at DSS (Figure 7). In the context of ice sheet dynamics, these results demonstrate a non-trivial connection between ice flow and the spacing of internal layers that is independent of the annual accumulation rate.

Due to the effects of horizontal advection of ice post-deposition, spatial variability in the flow disturbance from undulations in the bed, and the evolution in vertical strain rate over glacial cycles, it is difficult to infer an accumulation history from layer thicknesses deep within the DSS ice core. To address these difficulties we plan to investigate the long-term history of the accumulation rate at Law Dome (over the last glacial cycle), using inverse methods and a three dimensional full-Stokes ice sheet model that incorporates a physically realistic description of ice rheology.

\section{Conclusions}

We present LD2017, a revised age model for the Law Dome ice core over the last 88 ka. LD2017 improves on previous incarnations as it provides smooth variations in layer thicknesses, and uncertainties are fully propagated throughout the model. Therefore, both the age-depth relationship and its corresponging uncertainty is accounted for in the model by using an ensemble approach, meaning an age range rather than single age time-point can be cited. In addition, we have used independent estimates of snow accumulation rate for gas-based age ties, such that the model is not dependent on simultaneous modelling of ages and accumulation rates. These improvements allow for more credible cross-dating and duration estimates of specific events or epochs with other existing and new records. 
Clim. Past Discuss., https://doi.org/10.5194/cp-2017-96

Manuscript under review for journal Clim. Past

Discussion started: 23 August 2017

(c) Author(s) 2017. CC BY 4.0 License.

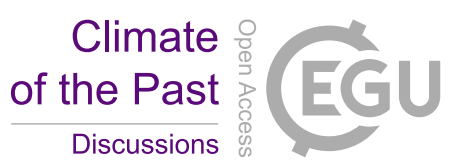

(c) (i)

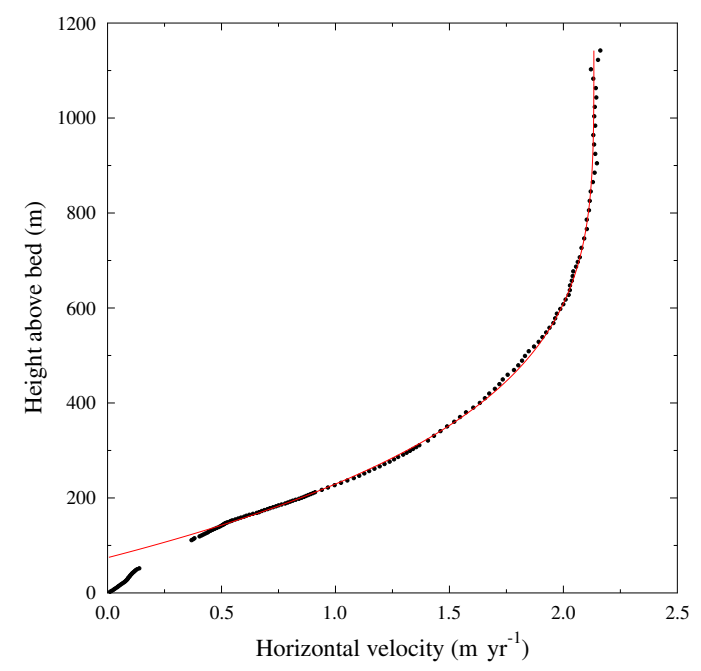

Figure 7. Horizontal ice velocity, parallel to the surface flow direction for the DSS borehole site at Law Dome (black dots). The red line depicts the velocity profile calculated according to Equation 6 based on the shape function of Lliboutry (1979). Note the vertical offset $(\sim 74 \mathrm{~m})$ of the derived profile due to the influence of bed undulations.

Author contributions. J Roberts and $\mathrm{T}$ van Ommen conceived the experiment, J Roberts conducted the simulations, all authors wrote the manuscript.

Competing interests. The authors declare that they have no conflict of interests

Acknowledgements. The Australian Antarctic Division provided funding and logistical support (ASAC 757, 4061, 4062). This work was sup-

5 ported by the Australian Government's Cooperative Research Centres Programme through the Antarctic Climate \& Ecosystems Cooperative Research Centre (ACE CRC). 
Clim. Past Discuss., https://doi.org/10.5194/cp-2017-96

Manuscript under review for journal Clim. Past

Discussion started: 23 August 2017

(c) Author(s) 2017. CC BY 4.0 License.

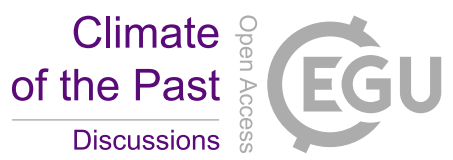

(c) (i)

\section{References}

Abramowitz, M. and Stegun, I., eds.: Handbook of Mathematical Functions, United States Department of Commerce, Washington, 1968.

Ashour, S. K. and Abdel-hameed, M. A.: Approximate skew normal distribution, Journal of Advanced Research, 1, 341-350, doi:10.1016/j.jare.2010.06.004, 2010.

Barnola, J., Pimienta, P., Raynaud, D., and Korotkevich, Y.: CO2-climate relationship as deduced from the Vostok ice core: a re-examination based on new measurements and on a re-evaluation of the air dating, Tellus B, 43, 83-90, 1991.

Curran, M., Ommen, T. V., and Morgan, V.: Seasonal characteristics of the major ions in the high-accumulation Dome Summit South ice core, Law Dome, Antarctica, Annals of Glaciology, 27, 385-390, http://staff.acecrc.org.au/ tas/home/reprints/1998-Annals-Curran-chem.pdf, 1998.

Dahl-Jensen, D., Morgan, V., and Elcheikh, A.: Monte Carlo inverse modelling of the Law Dome (Antarctica) temperature profile, Annals of Glaciology, 29, 145-150, 1999.

Dansgaard, W. and Johnsen, S.: A flow model and a time scale for the ice core from Camp Century, Greenland, Journal of Glaciology, 8 , 215-223, 1969.

Etheridge, D.: Dynamics of the Law Dome ice cap, Antarctica, as found from bore-hole measurements, Annals of Glaciology, 12, 46-50, 1989.

Etheridge, D., Steele, L., Francey, R., and Langenfelds, R.: Atmospheric methane between 1000 AD and present: Evidence of anthropogenic emissions and climatic variability, Journal of Geophysical Research, 103, 15 979-15 993, 1998.

Freitag, J., Kipfstuhl, S., Laepple, T., and Wilhelms, F.: Impurity-controlled densification: a new model for stratified polar firn, Journal of Glaciology, 59, 1163-1169, doi:10.3189/2013JoG13J042, 2013.

20 Friedman, J. H. and Silverman, B. W.: Flexible Parsimonious and Smoothing Additive Modeling, Technometrics, 31, 3-21, 1989.

Fudge, T. J., Waddington, E. D., Conway, H., Lundin, J. M. D., and Taylor, K.: Interpolation methods for Antarctic ice-core timescales: application to Byrd, Siple Dome and Law Dome ice cores, Climate of the Past, 10, 1195-1209, doi:10.5194/cp-10-1195-2014, http: //www.clim-past.net/10/1195/2014/, 2014.

Gradshteyn, I. and Ryzhik, I.: Table of Integrals, Series, and Products, Academic Press Inc., Florida, 1980.

Helsen, M. M., van den Broeke, M. R., van de Wal, R. S. W., van de Berg, W. J., van Meijgaard, E., Davis, C. H., Li, Y., and Goodwin, I.: Elevation changes in Antarctica mainly determined by accumulation variability., Science (New York, N.Y.), 320, 1626-1629, doi:10.1126/science.1153894, 2008.

Jouzel, J., Lorius, C., Petit, J. R., Genthon, C., Barkov, N. I., Kotlyakov, V. M., and Petrov, V. M.: Vostok ice core: a continuous isotope temperature record over the last climatic cycle (160,000 years), Nature, 329, 403-408, doi:10.1038/329403a0, 1987.

Jouzel, J., Vimeux, F., Caillon, N., Delaygue, G., Hoffmann, G., Masson-Delmotte, V., and Parrenin, F.: Magnitude of isotope/temperature scaling for interpretation of central Antarctic ice cores, Journal of Geophysical Research: Atmospheres, 108, n/a-n/a, doi:10.1029/2002JD002677, http://dx.doi.org/10.1029/2002JD002677, 4361, 2003.

Kaspers, K. A., van de Wal, R. S. W., van den Broeke, M. R., Schwander, J., van Lipzig, N. P. M., and Brenninkmeijer, C. A. M.: Model calculations of the age of firn air across the Antarctic continent, Atmospheric Chemistry and Physics, 4, 1365-1380, doi:10.5194/acp-41365-2004, http://www.atmos-chem-phys.net/4/1365/2004/, 2004.

Kobashi, T., Severinghaus, J. P., Brook, E. J., Barnola, J.-M., and Grachev, A. M.: Precise timing and characterization of abrupt climate change 8200 years ago from air trapped in polar ice, Quaternary Science Reviews, 26, 1212-1222, 2007. 
Clim. Past Discuss., https://doi.org/10.5194/cp-2017-96

Manuscript under review for journal Clim. Past

Discussion started: 23 August 2017

(c) Author(s) 2017. CC BY 4.0 License.

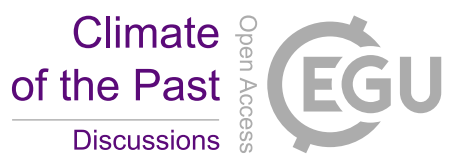

(c) (i)

Lambert, F., Delmonte, B., Petit, J. R., Bigler, M., Kaufmann, P. R., Hutterli, M. A., Stocker, T. F., Ruth, U., Steffensen, J. P., and Maggi, V.: Dust-climate couplings over the past 800,000 years from the EPICA Dome C ice core, Nature, 452, 616-619, 2008.

Landais, A., Barnola, J., Kawamura, K., Caillon, N., Delmotte, M., Van Ommen, T., Dreyfus, G., Jouzel, J., Masson-Delmotte, V., Minster, B., Freitag, J., Leuenberger, M., Schwander, J., Huber, C., Etheridge, D., and Morgan, V.: Firn-air $\delta 15 \mathrm{~N}$ in modern polar sites and glacial-interglacial ice: a model-data mismatch during glacial periods in Antarctica?, Quaternary Science Reviews, 25, 49-62, doi:10.1016/j.quascirev.2005.06.007, 2006.

Ligtenberg, S. R. M., Helsen, M. M., and van den Broeke, M. R.: An improved semi-empirical model for the densification of Antarctic firn, The Cryosphere, 5, 809-819, doi:10.5194/tc-5-809-2011, 2011.

Lliboutry, L. A.: A critical review of analytical approximate solutions for steady state velocities and temperature in cold ice sheets, Zeitschift fur Gletscherkunde und Glazialgeologie Bd, 15, 135-148, 1979.

Morgan, V. and van Ommen, T.: Seasonality in late-Holocene climate from ice-core records, The Holocene, 7, 351-354, 1997.

Morgan, V., Wookey, C., LI, J., van Ommen, T., Skinner, W., and Fitzpatrick, M.: Site information and initial results from deep ice drilling on Law Dome, Antarctica, Journal of Glaciology, 43, 3-10, 1997.

Morgan, V., van Ommen, T., Elcheikh, A., and Jun, L.: Variations in shear deformation rate with depth at Dome Summit South, Law Dome, East Antarctica, Annals of Glaciology, 27, 135-139, 1998.

Morgan, V., Delmotte, M., Van Ommen, T., Jouzel, J., Chappellaz, J., Woon, S., Masson-Delmotte, V., and Raynaud, D.: Relative timing of deglacial climate events in Antarctica and Greenland, Science, 297, 1862-1864, 2002.

Murphy, D. M. and Koop, T.: Review of the vapour pressures of ice and supercooled water for atmospheric applications, Quarterly Journal of the Royal Meteorological Society, 131, 1539-1565, doi:10.1256/qj.04.94, http://dx.doi.org/10.1256/qj.04.94, 2005.

Parrenin, F., Dreyfus, G., Durand, G., Fujita, S., Gagliardini, O., Gillet, F., Jouzel, J., Kawamura, K., Lhomme, N., Masson-Delmotte, V., Ritz, C., Schwander, J., Shoji, H., Uemura, R., Watanabe, O., and Yohida, N.: 1-D-ice flow modelling at EPICA Dome C and Dome Fuji, East Antarctica, Climate Of The Past, 3, 243-259, 2007.

Parrenin, F., Petit, J. R., Masson-Delmotte, V., Wolff, E., Basile-Doelsch, I., Jouzel, J., Lipenkov, V., Rasmussen, S. O., Schwander, J., Severi, M., Udisti, R., Veres, D., and Vinther, B. M.: Volcanic synchronisation between the EPICA Dome C and Vostok ice cores (Antarctica) 0-145 kyr BP, Climate of the Past, 8, 1031-1045, 2012.

Paterson, W.: The Physics Of Glaciers (Third Edition), Butterworth Heinemann, Oxford, 1994.

Pedersen, M. and Chipperfield, A.: Simplifying particle swarm optimization, Applied Soft Computing, 10, doi:10.1016/j.asoc.2009.08.029, 2010.

Pedro, J. B., van Ommen, T. D., Rasmussen, S. O., Morgan, V. I., Chappellaz, J., Moy, A. D., Masson-Delmotte, V., and Delmotte, M.: The last deglaciation: timing the bipolar seesaw, Climate of the Past, 7, 671-683, 2011.

Peltier, W.: Global Glacial Isostasy and the Surface of the Ice-Age Earth: The ICE-5G (VM2) Model and GRACE, Ann. Rev. Earth and Planet. Sci., 32, 111-149, 2004.

Plummer, C. T., Curran, M. A. J., van Ommen, T. D., Rasmussen, S. O., Moy, A. D., Vance, T. R., Clausen, H. B., Vinther, B. M., and Mayewski, P. a.: An independently dated 2000-yr volcanic record from Law Dome, East Antarctica, including a new perspective on the dating of the 1450s CE eruption of Kuwae, Vanuatu, Climate of the Past, 8, 1929-1940, doi:10.5194/cp-8-1929-2012, 2012.

Roberts, J., Plummer, C., Vance, T., van Ommen, T., Moy, A., Poynter, S., Treverrow, A., Curran, M., and George, S.: A two thousand year annual record of snow accumulation rates for Law Dome, East Antarctica, Climate of the Past, 11, 697-707, 2015. 
Clim. Past Discuss., https://doi.org/10.5194/cp-2017-96

Manuscript under review for journal Clim. Past

Discussion started: 23 August 2017

(c) Author(s) 2017. CC BY 4.0 License.

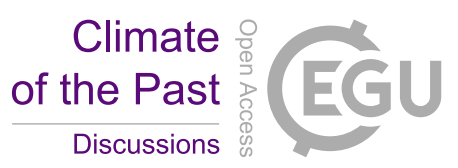

(c) (i)

Roberts, J. L., Moy, A. D., van Ommen, T. D., Curran, M. A. J., Worby, A. P., Goodwin, I. D., and Inoue, M.: Borehole temperatures reveal a changed energy budget at Mill Island, East Antarctica, over recent decades, The Cryosphere, 7, 263-273, doi:10.5194/tc-7-263-2013, 2013.

Roberts, N.: The Limit of $\delta^{1} 80$ Annual Layer Detection in the Law Dome Ice Cap, University of Tasmania Honours Thesis, 1999.

5 Schlichting, H.: Boundary layer theory, McGraw-Hill, New York, 6th edn., 1968.

Scholle, M., Wierschem, a., and Aksel, N.: Creeping films with vortices over strongly undulated bottoms, Acta Mechanica, 168, 167-193, doi:10.1007/s00707-004-0083-4, 2004.

Siegert, M. J.: Glacial-interglacial variations in central East Antarctic ice accumulation rates, Quaternary Science Reviews, 22, 741-750, 2003.

Spahni, R., Schwander, J., Flückiger, J., Stauffer, B., Chappellaz, J., and Raynaud, D.: The attenuation of fast atmospheric CH4 variations recorded in polar ice cores, Geophysical Research Letters, 30, 1571, doi:10.1029/2003GL017093, 2003.

Stenni, B., Masson-Delmotte, V., Selmo, E., Oerter, H., Meyer, H., Röthlisberger, R., Jouzel, J., Cattani, O., Falourd, S., Fischer, H., Hoffmann, G., Iacumin, P., Johnsen, S. J., Minster, B., and Udisti, R.: The deuterium excess records of EPICA Dome C and Dronning Maud Land ice cores (East Antarctica), Quaternary Science Reviews, 29, 146-159, 2010.

Trudinger, C., Enting, I., Etheridge, D., Francey, R., Levchenko, V., and Steele, L.: Modeling air movement and bubble trapping in firn, Journal of Geophysical Research, 102, 6747-6763, 1997.

van Ommen, T., Morgan, V., Jacka, T., S, W., and Elcheikh, A.: Near-surface temperatures in the Dome Summit South (Law Dome, East Antarctica) borehole, Annals of Glaciology, 29, 141-144, 1999.

van Ommen, T. D. and Morgan, V.: Peroxide concentrations in the Dome Summit South ice core, Law Dome, Antarctica, Journal of Geophysical Research, 101, 15 147-15 152, 1996.

van Ommen, T. D. and Morgan, V.: Calibrating the ice core paleothermometer using seasonality, Journal of Geophysical Research, 102, 9351-9357, doi:10.1029/96JD04014, 1997.

van Ommen, T. D., Morgan, V., and Curran, M. A. J.: Deglacial and Holocene changes in accumulation at Law Dome, East Antarctica, Annals of Glaciology, 39, 359-365, doi:10.3189/172756404781814221, 2004.

25 Veres, D., Bazin, L., Landais, A., Toyé Mahamadou Kele, H., Lemieux-Dudon, B., Parrenin, F., Martinerie, P., Blayo, E., Blunier, T., Capron, E., Chappellaz, J., Rasmussen, S. O., Severi, M., Svensson, A., Vinther, B., and Wolff, E. W.: The Antarctic ice core chronology (AICC2012): an optimized multi-parameter and multi-site dating approach for the last 120 thousand years, Climate of the Past, 9, 1733$1748,2013$.

Whitehouse, P. L., Bentley, M. J., and Le Brocq, A. M.: A deglacial model for Antarctica: geological constraints and glaciological modelling as a basis for a new model of Antarctic glacial isostatic adjustment, Quaternary Science Reviews, 32, 1-24, doi:10.1016/j.quascirev.2011.11.016, 2012a.

Whitehouse, P. L., Bentley, M. J., Milne, G. A., King, M. A., and Thomas, I. D.: A new glacial isostatic adjustment model for Antarctica: calibrated and tested using observations of relative sea-level change and present-day uplift rates, Geophysical Journal International, 190, 1464-1482, doi:10.1111/j.1365-246X.2012.05557.x, 2012b.

Wierschem, A., Scholle, M., and Aksel, N.: Vortices in flim flow over strongly undulated bottom profiles at low Reynolds numbers, Physics of Fluids, 15, 426-435, doi:10.1061/1.1533075, 2003. 